\title{
Subtidal Hydroids (Cnidaria) of Northumberland Strait, Atlantic Canada, with Observations on Their Life Cycles and Distributions
}

\author{
DALE R. CALDER \\ Centre for Biodiversity and Conservation Biology, Royal Ontario Museum, 100 Queen's Park, Toronto, Ontario M5S 2 C6 \\ Canada; and Department of Zoology, University of Toronto, Toronto, Ontario M5S 1A1 Canada.
}

Calder, Dale R. 2003. Subtidal hydroids (Cnidaria) of Northumberland Strait, Atlantic Canada, with observations on their life cycles and distributions. Canadian Field-Naturalist 117(4): 555-564.

Hydroids were examined in collections from a biological survey of Northumberland Strait undertaken by Fisheries and Oceans Canada from June to August 1975. No investigations have been undertaken previously on hydroids of the study area. Fortyeight species referable to 12 families were present in the samples, with Sertulariidae dominating in both numbers of species (12) and frequency. Gonophores were found in 30 of the species. As usual in hydroids of higher latitudes, a majority of those represented do not have a medusa stage in their life cycle. Gonophores in 42 of the 48 species are known to be fixed sporosacs while free medusae or medusoids occur in only six. Two major species groups were distinguished in a numerical analysis of hydroid species/station data. One of these groups included the three most ubiquitous species (Calycella syringa, Hydrallmania falcata, Sertularia latiuscula) together with 15 others most prevalent in samples from shallower $(<20 \mathrm{~m})$ and warmer stations. The second group included species occurring primarily in samples from stations in deeper $(>20 \mathrm{~m})$ and mostly colder waters. Two species (Lafoeina tenuis, Halecium lankesteri) are new to the Atlantic coast of North America. Eight others (Bougainvillia sp., Eudendrium dispar, Eudendrium ramosum, Cuspidella humilis, Opercularella pumila, Halecium scutum, Halecium sessile, Diphasia fallax) are reported in the southwestern Gulf of St. Lawrence for the first time. The subtidal hydroid fauna in open waters of Northumberland Strait is a cold-water assemblage typical of the boreal zone in the western North Atlantic, and no relict warm-temperate species were found.

Key Words: hydroids, Cnidaria, Hydrozoa, Northumberland Strait, Prince Edward Island, Nova Scotia, New Brunswick, Gulf of St. Lawrence, reproduction, zoogeography.

Research on hydroids in Atlantic Canada began with Stimpson's (1854) synopsis of marine invertebrates in waters around Grand Manan Island, at the mouth of the Bay of Fundy, New Brunswick. Since then, however, fewer than two-dozen systematic accounts have been published on hydroids of the region. Most available knowledge was summarized in a guidebook, now more than six decades old, on species of the Atlantic coast of North America (Fraser 1944). Original information on hydroids of the southwestern Gulf of St. Lawrence is limited to five reports (Whiteaves 1901; Stafford 1912; Fraser 1926, 1927, 1944). None of these dealt with the fauna of Northumberland Strait, a sea channel separating Prince Edward Island from New Brunswick and Nova Scotia.

The southwestern Gulf of St. Lawrence, including Northumberland Strait, is biologically productive and of longstanding biogeographic interest (Ganong 1890). Being relatively shallow, waters undergo a wide annual range of temperature. Ice forms in the area during winter, while surface temperatures may approach or exceed $20^{\circ} \mathrm{C}$ in summer. As a result, a number of eurytopic temperate to warm-temperate species (e.g., the molluscs Crassostrea virginica, Mercenaria mercenaria, Mulinia lateralis, and Urosalpinx cinerea, the barnacle Balanus improvisus, the decapods Ovalipes ocellatus and Rithropanopeus harrisii, and the estuarine hydroid Garveia franciscana) occur in some localities. These invertebrates, considered relicts of a warmer period, are generally thought to be isolated from principal populations of their species occurring further south along the east coast of the United States by perpetually cold waters along much of the outer coast of Nova Scotia, the lower Bay of Fundy, and the northeastern Gulf of Maine (Ganong 1890; Whiteaves 1901; Fraser 1926; Bousfield 1960; Bousfield and Thomas 1975).

Objectives of this study were to census the subtidal hydroids of Northumberland Strait in the southwestern Gulf of St. Lawrence, and to determine their reproductive states, predominant life cycle patterns, and geographic affinities.

\section{Materials and Methods}

Materials examined were collected as part of the 1975 Northumberland Strait Project undertaken by the St. Andrews Biological Station, Fisheries and Oceans Canada. Marine invertebrates from this biological survey, including the hydroids studied here, were subsequently deposited at the Royal Ontario Museum (Carson 1985). Ninety-six stations were occupied between June and August 1975, during R/V Harengus Cruise Number 120, along a series of 13 transects extending across the strait in sequence from its northwestern to northeastern entrances into the Gulf of St. Lawrence. Samples of epibenthos were collected by beam trawl 
TABLE 1. Stations in Northumberland Strait, eastern Canada, at which hydroids were collected during R/V Harengus cruise 120, 1975. $\mathrm{BT}=$ beam trawl; $\mathrm{SD}=$ scallop drag; $\mathrm{NR}=$ not recorded.

\begin{tabular}{|c|c|c|c|c|c|c|c|c|}
\hline Station & Date & $\begin{array}{c}\text { North } \\
\text { Latitude }\end{array}$ & $\begin{array}{c}\text { West } \\
\text { Longitude }\end{array}$ & Gear & $\begin{array}{l}\text { Depth } \\
\text { (m) }\end{array}$ & $\begin{array}{l}\text { Temp. } \\
\left({ }^{\circ} \mathrm{C}\right)\end{array}$ & Bottom Type & $\begin{array}{c}\text { Number of } \\
\text { Species }\end{array}$ \\
\hline \multicolumn{9}{|c|}{ Northwestern Sector } \\
\hline 2 & $11-$ VI-75 & $46^{\circ} 57^{\prime} 45^{\prime \prime}$ & $64^{\circ} 45^{\prime} 15^{\prime \prime}$ & BT & 13 & 11.0 & NR & 6 \\
\hline 3 & $11-\mathrm{VI}-75$ & $46^{\circ} 57^{\prime} 45^{\prime \prime}$ & $64^{\circ} 39^{\prime} 10^{\prime \prime}$ & BT & 22 & 13.0 & sandy & 11 \\
\hline 4 & $11-\mathrm{VI}-75$ & $46^{\circ} 57^{\prime} 45^{\prime \prime}$ & $64^{\circ} 33^{\prime} 40^{\prime \prime}$ & BT & 23 & 6.7 & sandy & 6 \\
\hline 5 & $12-\mathrm{VI}-75$ & $46^{\circ} 57^{\prime \prime} 45^{\prime \prime}$ & $64^{\circ} 25^{\prime} 15^{\prime \prime}$ & BT & 36 & 6.6 & sandy/muddy & 2 \\
\hline 10 & $18-\mathrm{VI}-75$ & $46^{\circ} 52^{\prime} 40^{\prime \prime}$ & $64^{\circ} 16^{\prime} 15^{\prime \prime}$ & BT & 16 & 9.8 & NR & 4 \\
\hline 11 & $18-V I-75$ & $46^{\circ} 52^{\prime} 20^{\prime \prime}$ & $64^{\circ} 22^{\prime} 15^{\prime \prime}$ & BT & 29 & 2.5 & NR & 9 \\
\hline 12 & 02-VII-75 & $46^{\circ} 52^{\prime} 15^{\prime \prime}$ & $64^{\circ} 24^{\prime} 45^{\prime \prime}$ & BT & 29 & 9.0 & shell/gravel/boulders & 13 \\
\hline 13 & 02-VII-75 & $46^{\circ} 51^{\prime} 30^{\prime \prime}$ & $64^{\circ} 39^{\prime} 50^{\prime \prime}$ & BT & 25 & 10.5 & NR & 18 \\
\hline 14 & 02-VII-75 & $46^{\circ} 51^{\prime} 20^{\prime \prime}$ & $64^{\circ} 42^{\prime} 40^{\prime \prime}$ & BT & 18 & 12.6 & boulders & 14 \\
\hline 18 & 03-VII-75 & $46^{\circ} 43^{\prime} 40^{\prime \prime}$ & $64^{\circ} 40^{\prime} 00^{\prime \prime}$ & SD & 18 & 11.7 & boulders & 19 \\
\hline 21 & 04-VII-75 & $46^{\circ} 44^{\prime} 00^{\prime \prime}$ & $64^{\circ} 32^{\prime} 30^{\prime \prime}$ & SD & 22 & 12.2 & NR & 8 \\
\hline 22 & 04-VII-75 & $46^{\circ} 44^{\prime} 10^{\prime \prime}$ & $64^{\circ} 30^{\prime} 10^{\prime \prime}$ & SD & 25 & 12.0 & mud/gravel/shell & 14 \\
\hline 24 & 04-VII-75 & $46^{\circ} 44^{\prime} 30^{\prime \prime}$ & $64^{\circ} 23^{\prime} 30^{\prime \prime}$ & SD & 11 & 15.5 & boulders & 12 \\
\hline \multicolumn{9}{|c|}{ West-central Sector } \\
\hline 25 & 04-VII-75 & $46^{\circ} 36^{\prime} 20^{\prime \prime}$ & $64^{\circ} 23^{\prime} 25^{\prime \prime}$ & SD & 07 & 17.0 & shell/gravel/boulders & 12 \\
\hline 26 & 01-VII-75 & $46^{\circ} 35^{\prime} 35^{\prime \prime}$ & $64^{\circ} 24^{\prime} 00^{\prime \prime}$ & BT & 13 & 14.2 & NR & 4 \\
\hline 30 & $26-V I-75$ & $46^{\circ} 27^{\prime} 25^{\prime \prime}$ & $64^{\circ} 30^{\prime} 05^{\prime \prime}$ & BT & 09 & 14.1 & sand & 6 \\
\hline 31 & 26-VI-75 & $46^{\circ} 26^{\prime} 30^{\prime \prime}$ & $64^{\circ} 30^{\prime} 55^{\prime \prime}$ & BT & 09 & 15.3 & sand & 12 \\
\hline 32 & $26-V I-75$ & $46^{\circ} 23^{\prime} 10^{\prime \prime}$ & $64^{\circ} 33^{\prime} 20^{\prime \prime}$ & SD & 05 & 16.2 & sand & 5 \\
\hline 33 & $13-$ VI-75 & $46^{\circ} 17^{\prime} 15^{\prime \prime}$ & $64^{\circ} 29^{\prime} 00^{\prime \prime}$ & BT & 22 & 16.8 & sand/mud & 1 \\
\hline 34 & $13-\mathrm{VI}-75$ & $46^{\circ} 18^{\prime} 35^{\prime \prime}$ & $64^{\circ} 25^{\prime} 00^{\prime \prime}$ & BT & 09 & 10.7 & sand/mud & 8 \\
\hline 35 & $13-$ VI-75 & $46^{\circ} 19^{\prime} 20^{\prime \prime}$ & $64^{\circ} 22^{\prime} 30^{\prime \prime}$ & BT & 14 & 11.4 & sand/mud & 14 \\
\hline 36 & $13-\mathrm{VI}-75$ & $46^{\circ} 20^{\prime} 15^{\prime \prime}$ & $64^{\circ} 20^{\prime} 00^{\prime \prime}$ & BT & 14 & 11.4 & shell/gravel/sand & 2 \\
\hline 38 & $10-\mathrm{VI}-75$ & $46^{\circ} 22^{\prime} 05^{\prime \prime}$ & $64^{\circ} 14^{\prime} 05^{\prime \prime}$ & BT & 13 & 10.8 & shell/gravel/sand & 7 \\
\hline 40 & $05-$ VI-75 & $46^{\circ} 24^{\prime} 00^{\prime \prime}$ & $64^{\circ} 08^{\prime} 35^{\prime \prime}$ & BT & 07 & 11.5 & shell/gravel/sand & 6 \\
\hline 42 & $03-$ VI-75 & $46^{\circ} 18^{\prime} 00^{\prime \prime}$ & $63^{\circ} 52^{\prime} 30^{\prime \prime}$ & BT & 14 & 11.5 & sand & 11 \\
\hline 43 & $03-V I-75$ & $46^{\circ} 14^{\prime} 10^{\prime \prime}$ & $63^{\circ} 54^{\prime} 15^{\prime \prime}$ & BT & 22 & 11.4 & mud & 7 \\
\hline 44 & $03-V I-75$ & $46^{\circ} 11^{\prime} 45^{\prime \prime}$ & $63^{\circ} 55^{\prime} 15^{\prime \prime}$ & BT & 11 & 11.6 & sand & 8 \\
\hline 45 & 24-VI-75 & $46^{\circ} 07^{\prime} 45^{\prime \prime}$ & $63^{\circ} 45^{\prime} 10^{\prime \prime}$ & BT & 09 & 15.1 & sand/mud & 6 \\
\hline 46 & 24-VI-75 & $46^{\circ} 09^{\prime} 30^{\prime \prime}$ & $63^{\circ} 45^{\prime} 30^{\prime \prime}$ & SD & 29 & 13.5 & shell/gravel/sand & 11 \\
\hline 48 & 24-VI-75 & $46^{\circ} 15^{\prime} 00^{\prime \prime}$ & $63^{\circ} 43^{\prime} 00^{\prime \prime}$ & BT & 09 & 14.6 & shell/gravel/sand & 14 \\
\hline \multicolumn{9}{|c|}{ East-central Sector } \\
\hline 49 & $10-$ VII-75 & $46^{\circ} 08^{\prime} 05^{\prime \prime}$ & $63^{\circ} 19^{\prime} 15^{\prime \prime}$ & BT & 09 & 14.8 & sand/mud & 4 \\
\hline 52 & 09-VII-75 & $46^{\circ} 01^{\prime} 45^{\prime \prime}$ & $63^{\circ} 27^{\prime} 50^{\prime \prime}$ & BT & 22 & 11.0 & mud & 2 \\
\hline 59 & 16-VII-75 & $45^{\circ} 54^{\prime} 10^{\prime \prime}$ & $63^{\circ} 04^{\prime} 40^{\prime \prime}$ & BT & 31 & 10.9 & NR & 1 \\
\hline 60 & 18 -VII-75 & $45^{\circ} 56^{\prime} 30^{\prime \prime}$ & $63^{\circ} 05^{\prime} 15^{\prime \prime}$ & BT & 27 & 10.8 & mud & 2 \\
\hline 61 & 18-VII-75 & $45^{\circ} 58^{\prime} 30^{\prime \prime}$ & $63^{\circ} 05^{\prime} 14^{\prime \prime}$ & BT & 22 & 14.5 & mud & 12 \\
\hline 62 & 18-VII-75 & $45^{\circ} 59^{\prime} 05^{\prime \prime}$ & $63^{\circ} 05^{\prime} 50^{\prime \prime}$ & BT & 22 & 13.5 & mud & 6 \\
\hline 65 & 30-VII-75 & $45^{\circ} 56^{\prime} 50^{\prime \prime}$ & $62^{\circ} 44^{\prime} 30^{\prime \prime}$ & BT & 09 & 12.3 & shell/gravel/sand & 7 \\
\hline 66 & 30-VII-75 & $45^{\circ} 55^{\prime} 45^{\prime \prime}$ & $62^{\circ} 43^{\prime} 50^{\prime \prime}$ & BT & 31 & 7.6 & mud & 14 \\
\hline 67 & 30-VII-75 & $45^{\circ} 55^{\prime} 15^{\prime \prime}$ & $62^{\circ} 40^{\prime} 40^{\prime \prime}$ & SD & 29 & 10.9 & mud & 17 \\
\hline 68 & 30-VII-75 & $45^{\circ} 49^{\prime} 30^{\prime \prime}$ & $62^{\circ} 39^{\prime} 30^{\prime \prime}$ & SD & 20 & 12.8 & mud & 8 \\
\hline 71 & 24-VII-75 & $45^{\circ} 43^{\prime} 40^{\prime \prime}$ & $62^{\circ} 35^{\prime} 40^{\prime \prime}$ & BT & 09 & 16.2 & sand & 1 \\
\hline 72 & 24-VII-75 & $45^{\circ} 43^{\prime} 00^{\prime \prime}$ & $62^{\circ} 35^{\prime} 00^{\prime \prime}$ & SD & 14 & 17.0 & mud & 2 \\
\hline 73 & 10-VIII-75 & $45^{\circ} 46^{\prime} 15^{\prime \prime}$ & $62^{\circ} 10^{\prime} 45^{\prime \prime}$ & BT & 14 & 14.6 & sand & 11 \\
\hline 74 & 10-VIII-75 & $45^{\circ} 47^{\prime} 00^{\prime \prime}$ & $62^{\circ} 11^{\prime} 40^{\prime \prime}$ & BT & 29 & 7.6 & mud & 3 \\
\hline 75 & 10-VIII-75 & $45^{\circ} 48^{\prime} 10^{\prime \prime}$ & $62^{\circ} 13^{\prime} 00^{\prime \prime}$ & BT & 32 & 6.2 & mud & 2 \\
\hline 76 & 31-VII-75 & $45^{\circ} 52^{\prime} 45^{\prime \prime}$ & $62^{\circ} 18^{\prime} 40^{\prime \prime}$ & BT & 31 & 5.3 & mud & 5 \\
\hline 78 & 31-VII-75 & $45^{\circ} 56^{\prime} 15^{\prime \prime}$ & $62^{\circ} 23^{\prime} 30^{\prime \prime}$ & BT & 36 & 6.1 & mud & 17 \\
\hline 79 & 31-VII-75 & $45^{\circ} 57^{\prime} 15^{\prime \prime}$ & $62^{\circ} 24^{\prime} 00^{\prime \prime}$ & BT & 36 & 3.4 & mud & 1 \\
\hline 80 & 31-VII-75 & $45^{\circ} 59^{\prime} 40^{\prime \prime}$ & $62^{\circ} 27^{\prime} 15^{\prime \prime}$ & BT & 14 & 11.6 & sand/mud & 10 \\
\hline 87 & 21-VII-75 & $45^{\circ} 51^{\prime} 15^{\prime \prime}$ & $62^{\circ} 01^{\prime} 15^{\prime \prime}$ & BT & 25 & 19.0 & mud & 1 \\
\hline \multicolumn{9}{|c|}{ Northeastern Sector } \\
\hline 84 & 24-VII-75 & $46^{\circ} 03^{\prime} 45^{\prime \prime}$ & $62^{\circ} 16^{\prime} 45^{\prime \prime}$ & BT & 34 & 13.5 & mud & 9 \\
\hline 86 & 24-VII-75 & $46^{\circ} 01^{\prime} 00^{\prime \prime}$ & $62^{\circ} 12^{\prime} 20^{\prime \prime}$ & BT & 34 & 14.0 & mud & 10 \\
\hline 90 & 22-VII-75 & $45^{\circ} 54^{\prime} 30^{\prime \prime}$ & $61^{\circ} 53 ' 10^{\prime \prime}$ & SD & 32 & 15.0 & mud & 1 \\
\hline 91 & 22-VII-75 & $46^{\circ} 00^{\prime} 10^{\prime \prime}$ & $61^{\circ} 57^{\prime} 30^{\prime \prime}$ & BT & 49 & 10.0 & mud & 1 \\
\hline 92 & 22-VII-75 & $46^{\circ} 04^{\prime} 45^{\prime \prime}$ & $62^{\circ} 00^{\prime} 00^{\prime \prime}$ & SD & 32 & 12.0 & boulders & 10 \\
\hline
\end{tabular}


at 68 of the stations, and by scallop drag at the remaining 28. Hydroids were identified in samples from 55 of the stations (Table 1), and presence or absence of gonophores was determined.

Species associations in the collection were determined by numerical analysis (Rohlf 1990) of a data matrix recording presence or absence of each of 48 species encountered overall at each of 55 stations. Qualitative similarity coefficients were computed using the SIMQUAL program, employing the PHI coefficient. Inverse (species-group) cluster analysis was then undertaken by the SAHN program employing the UPGMA clustering method and using a beta value of -0.25 .

\section{Study Area}

Northumberland Strait separates Prince Edward Island from New Brunswick and Nova Scotia in Atlantic Canada. Some $330 \mathrm{~km}$ in length, it comprises a moderately sheltered central region with funnel-shaped openings to the Gulf of St. Lawrence at its northwestern and northeastern ends. Minimum width across the strait is $12 \mathrm{~km}$, maximum depth is approximately $50 \mathrm{~m}$, tidal range averages about $3 \mathrm{~m}$, salinities are typically euhaline $(>30 \%)$, and the shoreline is predominantly sandy. Surface waters of the strait freeze over in winter but approach or exceed $20^{\circ} \mathrm{C}$ in summer.

At 96 stations occupied in late spring and summer during the 1975 Northumberland Strait Project, water temperatures varied from $2.5^{\circ} \mathrm{C}$ (Station 11 ) to $19.5^{\circ} \mathrm{C}$ (Stations 81, 89). Station depths ranged from $5 \mathrm{~m}$ (Stations 32, 57) to $49 \mathrm{~m}$ (Station 91). Bottoms consisted primarily of boulders or sand in the Northwestern Sector of the strait (Stations 1-24, north of $\left.46^{\circ} 40^{\prime} \mathrm{N}\right)$, shell/gravel/sand or sand in the Westcentral Sector (Stations 25-48, eastward to $63^{\circ} 40^{\prime} \mathrm{W}$ ), mud in the East-central Sector (Stations 49-80, 87, and 88 , eastward to a line from Cape Bear $\left[46^{\circ} 00^{\prime} \mathrm{N}\right.$, $62^{\circ} 28^{\prime} \mathrm{W}$ ] to Cape George [61 $\left.\left.56^{\prime} \mathrm{N}, 45^{\circ} 53^{\prime} \mathrm{W}\right]\right)$, and mud or boulders in the Northeastern Sector (Stations 81-86 and 89-96, northeast of the East-central Sector).

\section{Results}

Hydroid diversity in Northumberland Strait was moderately low, with 48 species identified in the samples (Table 2). Leptothecates accounted for 40 of these and anthoathecates eight. Five of the species (Calycella syringa, Hydrallmania falcata, Sertularia latiuscula, Sertularella polyzonias, Obelia longissima), all leptothecates, were found at 24 or more of the 96 stations. These and six other ubiquitous species (Symplectoscyphus tricuspidatus, Abietinaria abietina, Hydractinia polyclina, Rhizocaulus verticillatus, Gonothyraea loveni, Lafoea dumosa) occurred in samples from all four sectors of the strait (Northwestern, West-central, East-central, and Northeastern). Two species (Lafoeina tenuis, Halecium lankesteri) are new to the Atlantic coast of North America. Eight others (Bougainvillia sp., Eudendrium dispar, Eudendrium ramosum, Cuspidella humilis, Opercularella pumila, Halecium scutum, Halecium sessile, Diphasia fallax) are reported in waters of the southwestern Gulf of St. Lawrence for the first time. Of the 12 families of hydroids represented in the collection, Sertulariidae dominated both in numbers of species (12) and frequency in the samples (Table 2).

Colonies with gonophores were observed in 30 of the 48 species from the collections (Table 2), although most specimens were infertile. Of 427 records of hydroid species, gonophores were present in 108 (25\%) but absent or undetected in the remaining 319 (75\%). Fertile colonies were noted in 26 of 50 specimen records of anthoathecate species but in only 82 of 377 records of leptothecate species.

The fauna was divisible ecologically into two major species groups (Table 2) based on results of an inverse cluster analysis. Group I included the three most ubiquitous species (Calycella syringa, Hydrallmania falcata, Sertularia latiuscula) as well as 15 others associated for the most part with stations in shallower and somewhat warmer waters (mean depth 15.4 m; mean water temperature $12.5^{\circ} \mathrm{C}$ ). Group II species, 30 in number, were generally associated with deeper and colder sites (mean depth $23.1 \mathrm{~m}$; mean water temperature $11.3^{\circ} \mathrm{C}$ ). Eight of these 30 (Keratosum maximum, Lafoeina tenuis, Halecium muricatum, Halecium scutum, Campanularia groenlandica, Orthopyxis integra, Grammaria gracilis, Lafoea gracillima) were found only at stations in the more exposed northwestern and northeastern entrances of the strait.

\section{Discussion}

Of the 48 species identified here from Northumberland Strait, 10 have not been reported before from the southwestern Gulf of St. Lawrence region (Bougainvillia sp., Eudendrium dispar, Eudendrium ramosum, Cuspidella humilis, Lafoeina tenuis, Opercularella pumila, Halecium lankesteri, Halecium scutum, Halecium sessile, Diphasia fallax). All of them, however, are regarded as typical of boreal Atlantic waters (Table 2) and they are unlikely to have been recently introduced. Hydroid species reported from other localities in the southwestern gulf, but not found here, are listed in Table 3.

Gonophores were observed in 30 of the species. It is not known whether colonies of the remaining 18 are fertile during summer in the area. Numerous factors, including water temperature, nutrition, environmental stresses, and in some species even lunar and diurnal cycles (e.g., Elmhirst 1925; Ballard 1942; Stebbing 1980; Arai 1987; Calder 1990, 1991; Cornelius 1990; Piraino 1991; Gili and Hughes 1995), are likely to influence physiological functions such as the periodicity and frequency of gonophore production and gamete or medusa release. Gonophore formation in hydroids appears to be decidedly seasonal in spe- 


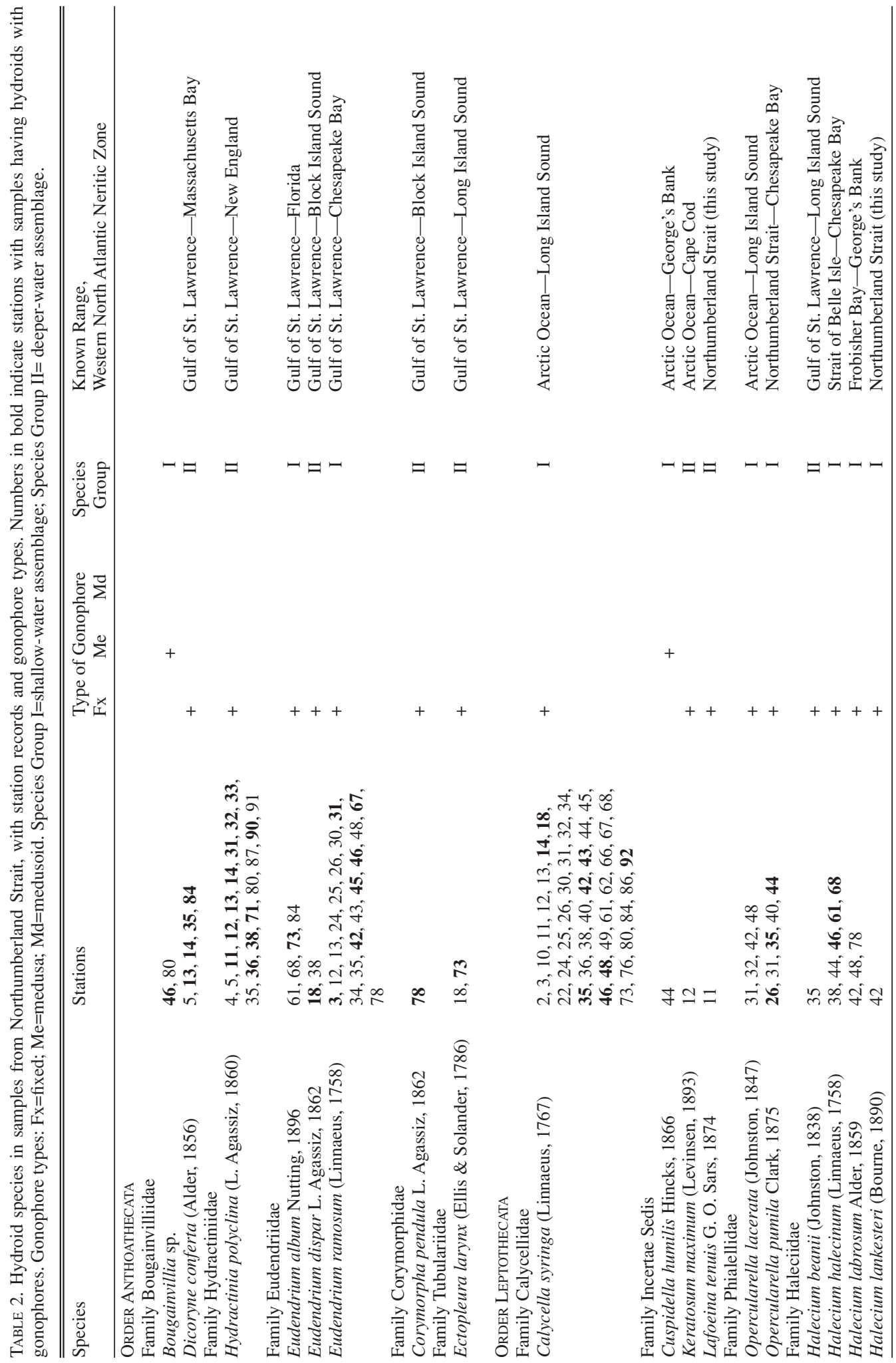




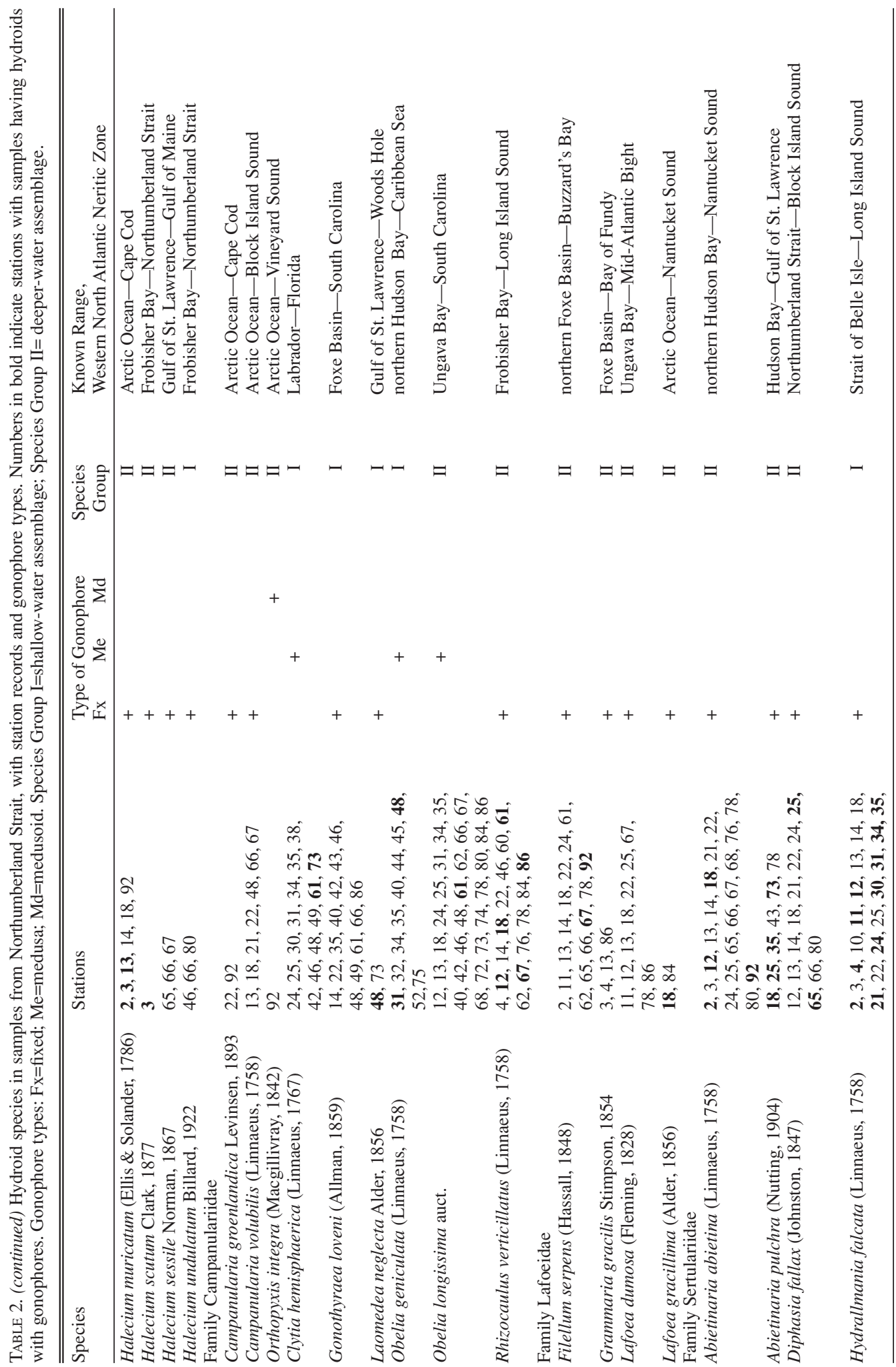




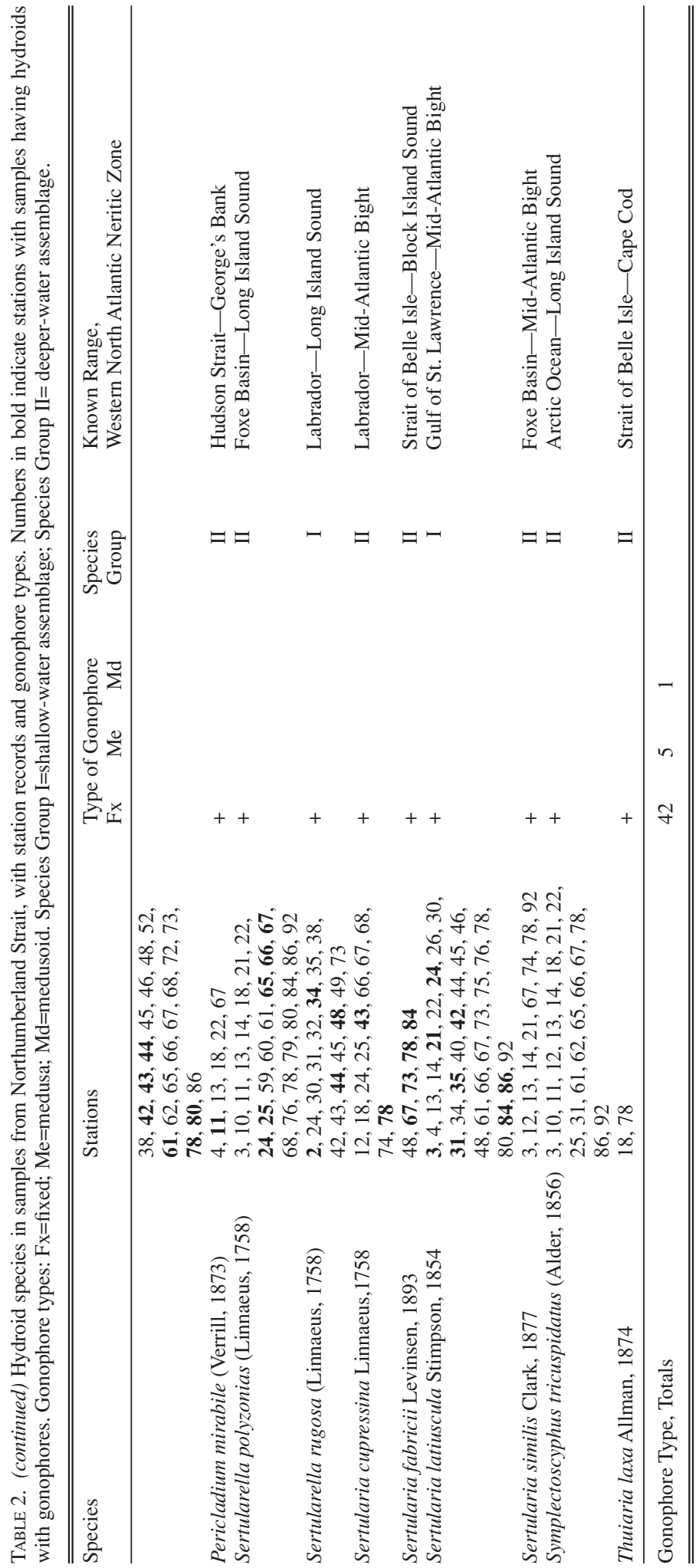




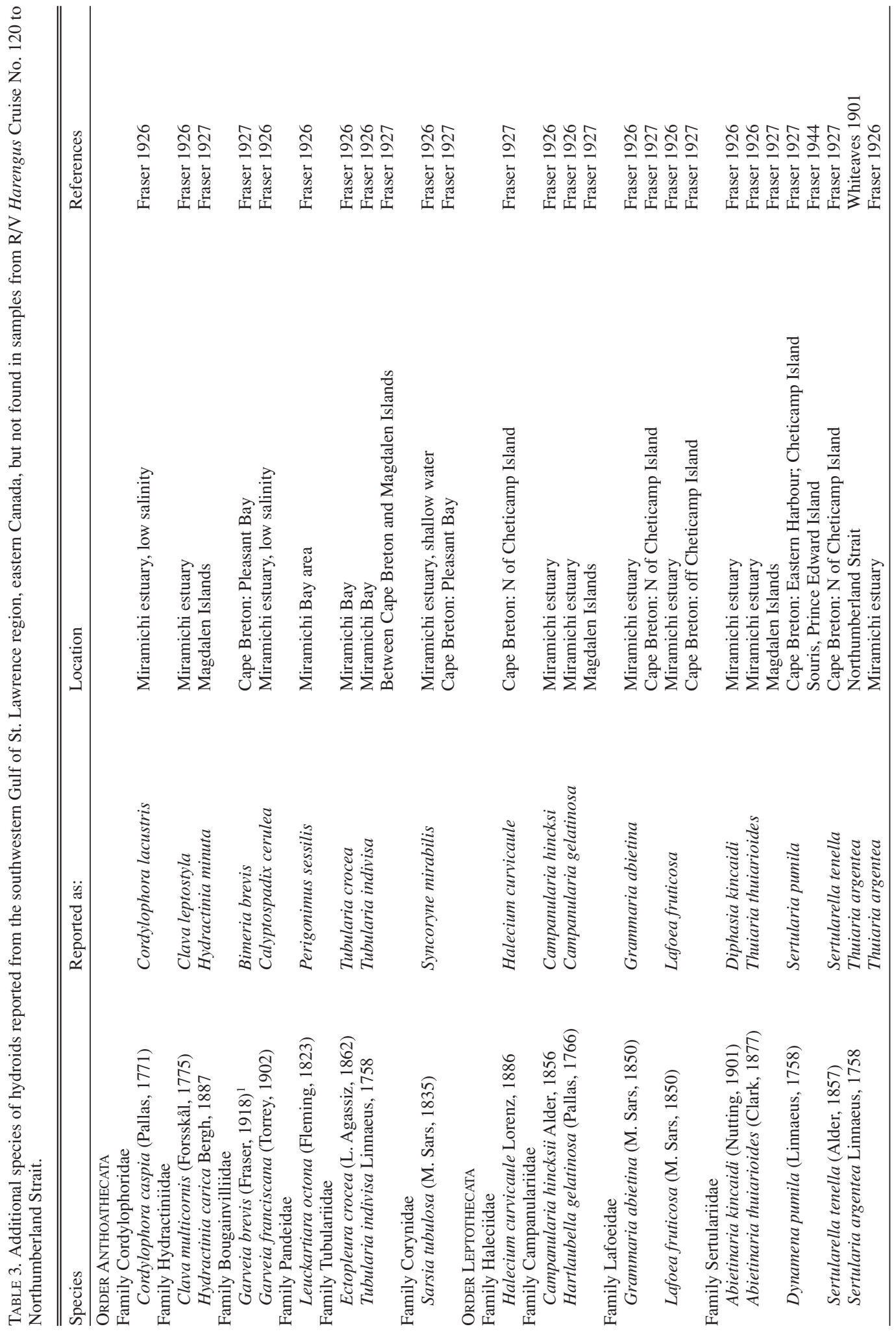




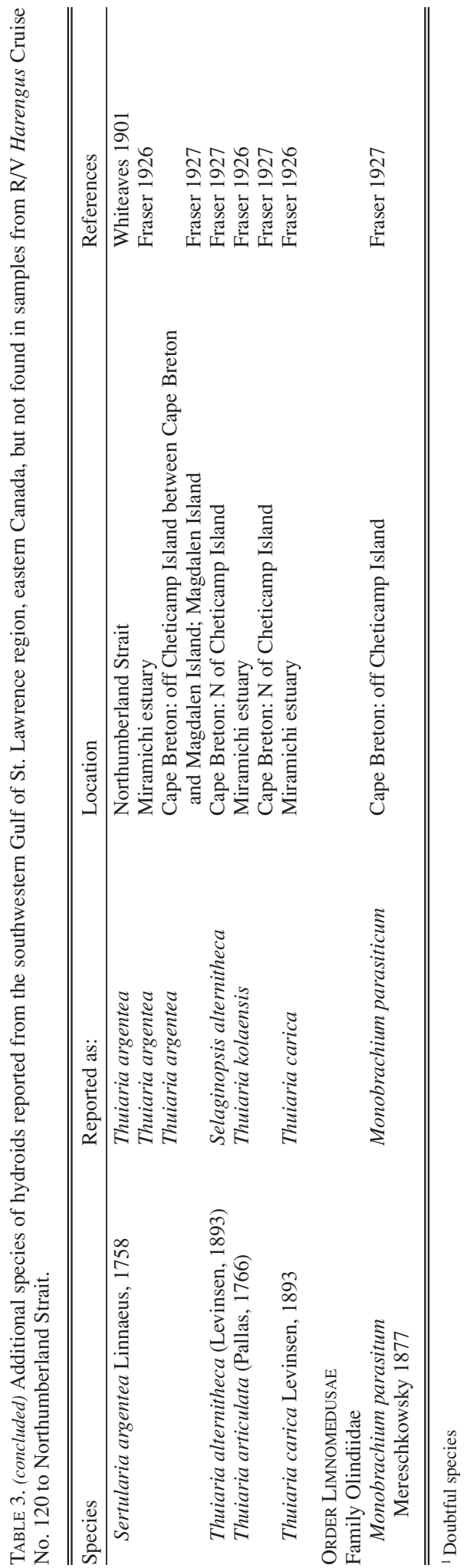

cies from areas subjected to significant annual water temperature ranges. Moreover, the duration of gonophore production in such areas is often considerably shorter than the period of trophosome activity for a given species, indicating that the range of factors conducive to production of gonophores is narrower than for vegetative activity and asexual colony growth. For example, gonophores were observed an average of 16 weeks a year in warm-water hydroid species vegetatively active for an average of 30 weeks, and 23 weeks a year in cold-water species active over an average of 32 weeks in southern Chesapeake Bay, Virginia (Calder 1990). None of these species produced gonophores or were vegetatively active throughout the year. In some of the rarer species from Northumberland Strait, specimens with gonophores may have simply been missed. However, the restricted sampling period (June through early August) in an area where temperatures vary widely from one season to another may also have been a factor. Stenothermal cold-water hydroids, especially those ranging into much higher latitudes, may not produce gonophores in Northumberland Strait during the warmest time of year when sampling was undertaken.

Life cycles in only six of the species are known to include a free medusa (Bougainvillia sp., Cuspidella humilis, Clytia hemisphaerica, Obelia geniculata, $O$. longissima) or a medusoid (Orthopyxis integra). In the remaining 42, gonophores are fixed sporosacs (Table 2). Life cycles are abbreviated and gonophores fixed in seven of eight anthoathecate species and 35 of 40 leptothecates.

Correlations have long been noted between life cycle patterns of hydroids and their biotope. For example, fixed gonophores predominate among species living as obligate associates of the seagrass Posidonia oceanica in the Mediterranean (Philbert 1935; Picard 1952; Boero 1987) and asexual reproduction by stolonization is prevalent. Reduced dispersal in seagrassinhabiting hydroids seems biologically advantageous because propagules tend to stay in the specialized habitat occupied by parent populations. Cornelius (1992a, b) and Calder (2000) noted that hydrozoans of oceanic islands and seamounts tended to be comprised largely of species with fixed gonophores instead of free medusae, thereby increasing the probability of larval retention within insular environments (see Johannesson 1988). Fixed gonophores were observed to be prevalent among hydroids living in cold waters along the western North Atlantic coast (Calder 1992), including the Gulf of St. Lawrence. By comparison, the proportion of species with a medusa stage in their life cycles was found to be greater at locations in lower latitudes, although hydroid species having free medusae outnumbered those having fixed gonophores only in temperate estuaries among localities studied. As with hydroids in high latitudes, including those of Northumberland Strait studied here, most species known from the deep-sea possess fixed gono- 
phores (Vervoort 1966; Calder 1997; Calder and Vervoort 1998). Indeed, non-pelagic larval development generally predominates among benthic invertebrate species of both high latitudes and the abyss (e.g., see Thorson 1950; Gage and Tyler 1991). The suppression of pelagic larval development typical in the benthic fauna of these environments appears correlated at least in part with limited food availability for meroplanktonic stages, given the short growing season for phytoplankton in polar waters and the oligotrophic conditions prevailing in much of the deep sea. Such "attribute syndromes" were also noted and discussed in relation to epilithic and epizoic hydroid assemblages from heavily dredged scallop grounds in the Bay of Fundy (Henry and Kenchington 2004). Each kind of hydroid life cycle, whether fixed gonophores, reduced and ephemeral medusoids, or free medusae, seems to offer advantages and disadvantages depending upon the biological circumstances of individual species. It is thus apparent why reproduction by both fixed gonophores and free medusae has been retained in Hydrozoa, and why medusa suppression has evidently occurred independently a number of times in both anthoathecates and leptothecates.

Although waters of Northumberland Strait are relatively shallow, two species groups correlated at least in part with depth and water temperature were distinguished in a numerical analysis. Group I comprised an assemblage of 18 species, including a suite of 15 that were most prevalent in samples from shallower $(<20 \mathrm{~m})$ and somewhat warmer stations. The remaining three species of the group (Calycella syringa, Hydrallmania falcata, Sertularia latiuscula), all quite eurythermal, were the most ubiquitous hydroids in the collection. Group II species predominated at stations in deeper $(>20 \mathrm{~m})$ and typically colder waters, and several of them were either limited to or most frequent in samples from exposed stations in the two entrances of the strait. Earlier, two depth-related assemblages of hydroids had been recognized by Fraser (1926) in nearby waters of the Miramichi estuary, Miramichi Bay, and the adjacent Gulf of St. Lawrence. Fraser reported that the fauna from depths of less than $15 \mathrm{~m}$ in the Miramichi area included a number of species commonly ranging farther south, while more northern or arctic species were represented at depths of $15 \mathrm{~m}$ or greater.

Water temperatures in shallow areas of Northumberland Strait were mostly moderate during the study. Nevertheless, none of the hydroids examined here is considered a warm-water species with a disjunct distribution along this coast. The reported ranges of two hydroids (Opercularella pumila, Diphasia fallax) were extended northward on this coast to Northumberland Strait, but both are cold-temperate species whose distributions are unlikely to be discontinuous. With no fewer than 30 of the 48 species from this study extending into subarctic or even Arctic waters
(Table 2), the subtidal hydroid fauna of the open strait is regarded here as an essentially cold-water (boreal) one. A marked zoogeographic affinity between hydroid assemblages of the southwestern Gulf of St. Lawrence (Miramichi and Cheticamp areas) with those of two continually cold-water areas elsewhere in Atlantic Canada (Canso, Nova Scotia; Passamaquoddy Bay, New Brunswick) was noted earlier (Calder 1992). A typically boreal fauna was also reported in a study of Bryozoa from the 1975 Northumberland Strait Project (Carson 1985).

\section{Acknowledgments}

All samples studied here were collected by staff of Fisheries and Oceans Canada, St. Andrews Biological Station, St. Andrews, New Brunswick. Michael Dadswell and Renate Carson arranged a transfer of the collection, together with collection data, to the Royal Ontario Museum, and I thank them both. The financial support of a research grant from the Natural Sciences and Engineering Research Council of Canada is acknowledged.

\section{Literature Cited}

Arai, M. N. 1987. Population ecology of the hydromedusae of Masset Inlet, British Columbia. Pages 107-116 in Modern trends in the systematics, ecology, and evolution of hydroids and hydromedusae. Edited by J. Bouillon, F. Boero, F. Cicogna, and P. F. S. Cornelius. Clarendon Press, Oxford.

Ballard, W. W. 1942. The mechanism for synchronous spawning in Hydractinia and Pennaria. Biological Bulletin (Woods Hole, Massachusetts) 82: 329-339.

Boero, F. 1987. Evolutionary implications of habitat selection in the hydroids of Posidonia oceanica meadows. Pages 251-256 in Modern trends in the systematics, ecology, and evolution of hydroids and hydromedusae. Edited by J. Bouillon, F. Boero, F. Cicogna, and P. F. S. Cornelius. Clarendon Press, Oxford.

Bousfield, E. L. 1960. Canadian Atlantic sea shells. National Museum of Canada, Ottawa.

Bousfield, E. L., and M. L. H. Thomas. 1975. Postglacial changes in distribution of littoral marine invertebrates in the Canadian Atlantic region. Proceedings of the Nova Scotia Institute of Science 27, supplement 3: 47-60.

Calder, D. R. 1990. Seasonal cycles of activity and inactivity in some hydroids from Virginia and South Carolina, USA. Canadian Journal of Zoology 68: 442-450.

Calder, D. R. 1991. Vertical zonation of the hydroid Dynamena crisioides (Hydrozoa, Sertulariidae) in a mangrove ecosystem at Twin Cays, Belize. Canadian Journal of Zoology 69: 2293-2999.

Calder, D. R. 1992. Similarity analysis of hydroid assemblages along a latitudinal gradient in the western North Atlantic. Canadian Journal of Zoology 70: 1078-1085.

Calder, D. R. 1997. Synopsis of hydroids from $1000 \mathrm{~m}$ and deeper in the western North Atlantic. Proceedings of the $6^{\text {th }}$ International Conference on Coelenterate Biology 1995: 85-90.

Calder, D. R. 2000. Assemblages of hydroids (Cnidaria) from three seamounts near Bermuda in the western North Atlantic. Deep-Sea Research I 47: 1125-1139. 
Calder, D. R., and W. Vervoort. 1998. Some hydroids (Cnidaria: Hydrozoa) from the Mid-Atlantic Ridge, in the North Atlantic Ocean. Zoologische Verhandelingen (Leiden) 319: 1-66.

Carson, R. 1985. Bryozoans of Northumberland Strait, Gulf of St. Lawrence. Pages 59-64 in Bryozoa: Ordovician to Recent. Edited by C. Nielsen and G. P. Larwood. Olsen and Olsen, Fredensborg.

Cornelius, P. F. S. 1990. Evolution in leptolid life-cycles (Cnidaria: Hydroida). Journal of Natural History 24: 579-594.

Cornelius, P. F. S. 1992a. Medusa loss in leptolid Hydrozoa (Cnidaria), hydroid rafting, and abbreviated life-cycles among their remote-island faunae: an interim review. Scientia Marina 56(2/3): 245-261.

Cornelius, P. F. S. 1992b. The Azores hydroid fauna and its origin, with discussion of rafting and medusa suppression. Arquipélago, Life and Earth Sciences 10: 75-99.

EImhirst, R. 1925. Lunar periodicity in Obelia. Nature (London) 116: 358-359.

Fraser, C. M. 1926. Hydroids of the Miramichi Estuary collected in 1918. Transactions of the Royal Society of Canada, $3^{\text {rd }}$ series, 20 (section 5): 209-214.

Fraser, C. M. 1927. The hydroids of the Cheticamp Expedition of 1917. Contributions to Canadian Biology and Fisheries 3: 325-329.

Fraser, C. M. 1944. Hydroids of the Atlantic coast of North America. University of Toronto Press, Toronto.

Gage, J. D., and P. A. Tyler. 1991. Deep-sea biology: a natural history of organisms at the deep-sea floor. Cambridge University Press, Cambridge.

Ganong, W. F. 1890. Southern invertebrates on the shores of Acadia. Transactions of the Royal Society of Canada 8(4): 167-185.

Gili, J.-M., and R. G. Hughes. 1995. The ecology of marine benthic hydroids. Annual Review of Oceanography and Marine Biology 33: 351-426.

Henry, L.-A., and E. Kenchington. 2004. Differences between epilithic and epizoic hydroid assemblages from commercial scallop grounds in the Bay of Fundy, northwest Atlantic. Marine Ecology Progress Series 266: 123-134.
Johannesson, K. 1988. The Paradox of Rockall: why is a brooding gastropod (Littorina saxatilis) more widespread than one having a planktonic larval dispersal stage $(L$. littorea)? Marine Biology 99: 507-513.

Philbert, M. 1935. Le phénomène de stolonisation chez trois espèces d'hydraires fixes sur des posidonies en Méditerranée. Bulletin de 1'Institut d'Océanographie de Monaco 663: $1-8$.

Picard, J. 1952. Les hydrozoaires des herbiers de zostéracées des côtes françaises de la Méditerranée. Vie et Milieu 2 (supplément): 217-233.

Piraino, S. 1991. The adaptive pattern of growth and reproduction of the colonial hydroid Clavopsella michaeli. Hydrobiologia 216/217: 229-234.

Rohlf, F. J. 1990. NTSYS-pc. Numerical taxonomy and multivariate analysis system, version 1.60. Applied Biostatistics Inc., Setauket, New York.

Stafford, J. 1912. On the fauna of the Atlantic coast of Canada. Fourth report. Contributions to Canadian Biology 1906-1910: 69-78.

Stebbing, A. R. D. 1980. Increase in gonozooid frequency as an adaptive response to stress in Campanularia flexuosa. Pages 27-32 in Developmental and cellular biology of coelenterates. Edited by P. Tardent and R. Tardent. Elsevier North-Holland Biomedical Press, Amsterdam.

Stimpson, W. 1854. Synopsis of the marine Invertebrata of Grand Manan; or the region about the mouth of the Bay of Fundy, New Brunswick. Smithsonian Contributions to Knowledge 6(5): 1-67.

Thorson, G. 1950. Reproductive and larval ecology of marine bottom invertebrates. Biological Reviews 25: 1-45.

Vervoort, W. 1966. Bathyal and abyssal hydroids. Galathea Report 8: 97-174.

Whiteaves, J. F. 1901. Catalogue of the marine Invertebrata of eastern Canada. Geological Survey of Canada Separate Report Number 722: 1-272.

Received 17 December 2001

Accepted 5 April 2004 